\title{
Effectiveness of CrossFit drills on muscular endurance and Consecutive attempts cases for youth weightlifters
}

\author{
Ahmed Awad ${ }^{1}$ \\ ${ }^{1}$ Department of sports training, faculty of physical education, Damietta University, Egypt.
}

Correspondence author: A. Awad, e-mail; dr ahawad@du.edu.eg,ORCID; https://orcid.org/0000-0002-1470-9294

\section{Introduction}

CrossFit is a core strength program, its functional movements are performed in wave of contraction from core to outward; these movements should involve multi joints and compound movements executed at high intensity. (Glassman, G., 2010; Sibley, B. A, 2012)

The functional movements in CrossFit are more important than the capacity. This means that athletes move large loads over long distance collectively and quickly including three main components (quickness, loads, distance) to produce high power. (Eather, N., Morgan, P. J., \& Lubans, D. R., 2016)

CrossFit is a contemporary method for training physical abilities through promotion of fitness generally from developing aerobic capacity, endurance, speed, balance and strength by comprising weightlifting exercises, aerobic condition and gymnastic performed in a complex manner. (Smith, M. M., Sommer, A. J., Starkoff, B. E., \& Devor, S. T. ,2013)

Weightlifting is one of the Olympic Games that need a variety of physical fitness preparation to succeed. It consists of two lifts snatch, clean and jerk. Both lifts need explosive strength, dynamic maximum strength, flexibility, agility, and muscular endurance that is need to develop continuously besides focusing in performance technique and psychological side. (Aján, T., \& Baroga, L.,1988; Baumann, W., Gross, V., Quade, K., Galbierz, P., \& Schwirtz, A.,1988)

The record achievement in both lifts will develop efficiently when the athlete's physical fitness integrated and primed together. Moreover, physical fitness has the biggest share in making champions (Garhammer, J., \& Takano, B., 1992; Ebada, K. H., 2013)

Muscular endurance can define as the ability to perform strength oriented action and repetition (Bompa, T. O., \& Buzzichelli, C., 2018). Similarly, it also define as the capacity of a muscle or muscles group to engage in a motor movement for a long time without the appearance of fatigue (Anderson, T., \& Kearney, J. T., 1982)

For weightlifting, muscle endurance (ME) considered as an essential element in training to provide the weightlifters with the ability to train continuously without fatigue. Eventually, the more you train, the more you improve your physical fitness and performance technique. This does not only promote the process of training, but this also promotes the competition warming up to competing effectively. ( Izquierdo, M., Ibáñez, J., Häkkinen, K., Kraemer, W. J., Ruesta, M., \& Gorostiaga, E. M., 2004) 
Weightlifting competition involves two sequenced lifts including snatch, clean and jerk. Each weightlifter has 3 attempts in snatch and another 3 attempts in clean and jerk (Hamill, B., 1994).

Snatch is defined as the ability of a weightlifter to stand behind the barbell gripping it with bending knees and pulling up the barbell in a signal movement showing full extend of arms above head while the legs are split or bent. During snatch, this continuous movement of the barbell should be close to the body, and not apart from the body except the feet may touch the platform. Finally, weightlifters must extend his legs and arms standing in motionless position and never lower the barbell until referees give a signal. (IWF Technical and Competition Rules \& Regulations, 2019)

Clean and jerk are two sequenced movements, including clean that is defined as the ability of weightlifter to stand behind the barbell gripping the barbell with bending knees and pulling up the barbell in a signal movement to the shoulder with splitting or bending legs. Then jerk that means pushing the barbell from the shoulders up with full strength and fully stretched arms in one motion with splitting or bending legs. Then athlete's legs must be lined up until referees give a signal of lowering the barbell (IWF Technical and Competition Rules \& Regulations, 2019).

Consecutive attempts (CA) are the case when the weightlifters execute the first or the second attempt and fall to lift it and then the player asked to attempt with the same weight in 2 minutes.

For example, player A is asked to execute the first attempt in snatch 120 kilograms, but he fails to lift it "no lift", then automatically the system asks him to lift the second attempt in the same weight within only 2 minutes starting from the announcer called his name until he already starts to lift.

This needs high muscular endurance and physical capacity to withstand stress and try to work against high intensity resistant for a long time without having full recovery

Youth weightlifters are the aged groups between 13 and 17 who could compete together in special categories.

The research aims to test the CrossFit training method in developing muscular endurance to increase training time against high intensity loads for weightlifters, also measuring its effect on players' success in CA cases in competitions to determine if this method is useful for weightlifting sports.

\section{Methods}

The experimental approach applied to the suit nature of the research (aims and sample), sample number (22) selected intentionally from youth weightlifters between 13 and 17, and grouped into two groups every group includes 11 weightlifter

After dividing the sample into two groups including the experimental group and the control group, the two groups matched in the basic measurements of age, height, training age and body weight as well as CA success rates and ME.

Then the CrossFit program implemented on the experimental sample to figure out the effective rates of these exercises on the $\mathbf{M E}$ and $\mathbf{C A}$ for youth weightlifters through calculating difference in rates between measurements before and after Appling the program.

The control group in the same level of CA, basic measurements and ME to be the mirror in explaining real devolvement rates through comparing its final measurements with the final measurements of the experimental group. 
To measure ME in the lights of its definition as the ability to force fatigue and still work against outer resistance for a long time (Hagberg, M. A. T. S.,1981). Six physical tests chosen to be relevant to weightlifting sport, clean repetition test, jerk repetition test, snatch repetition test, front squat repetition test, back squat repetition test and clean pull up (deadlift) repetition test.

For CA, which means the trial to lift the same weight within 2 minutes after failure to do that in the first or second attempts, refers to the repetition of the same effort against high intensity (IWF) loads. This tested by competition simulation test.

The competition simulation (CS) test held by setting all competition atmosphere design; including the three referees and the jury committee even, the attendees invited. After warming up the highest record for every weightlifter shown and weightlifters asked to lift it in their three attempts in the competition simulation separated by only 2 minutes.

This test done for both groups, including experimental and control group in snatch and clean and jerk before and after applying the programs.

Finally, statistics are calculated to show the differences between the pre-measurements and postmeasurements to every group (experimental and control). In addition, statistics showed the differences between the two finally measurements to both groups (experimental and control) to figure out improvement rates in $\mathbf{C A}$ and $\mathbf{M E}$ to every group and between them.

\section{CROSSFIT Program details}

The program lasted for 8 weeks, 3 unitslworkouts per week" Saturday, Monday, Wednesday", every unit duration 120 minutes, and it started from Saturday 119\2018 to Wednesday 24\10\2018.

First measurements take period 1 week before starting the program from Saturday $25 \backslash 8 \backslash 2018$ until Friday $31 \backslash 8 \backslash 2018$, and the same period for finally measurements from Saturday 27\10\2018 until Friday 2\11\2018.

The ME physical tests are done according to the following sequences Monday's clean repetition test and back squat repetition test, Wednesday's jerk repetition test and clean pull up repetition test, Friday's snatch repetition test and front squat test.

The CA competition simulation test executed on the first day of the week of measurements on Saturdays.

\section{Statistical analysis}

All statistical are done with Spss application and Excel application. First; descriptive statistics are used (mean, Std. Deviation, average) for the whole sample, also skewness equation applied for homogeneity in basics measurements (age, bodyweight, tall, training age), also in ME and CA tests results.

Second, after dividing the sample into two groups, equivalent calculated through T-test equation in basics measurements and $\mathbf{M E}$ and $\mathbf{C A}$ tests results.

Finally, T-test applied to find out the differences between pre-measurements and post-measurements for every group and between the post-measurements of the two groups.

\section{Results}


Tables 1 shows the average, median, Std. Deviation and skewness for the whole sample to make sure that all matching in basics measurements (age, tall, training age, bodyweight) also for ME and CA tests.

Table 1

Average, Std. Deviation, main skewness in basics measurements, ME tests and CA test. (n=22)

\begin{tabular}{|c|c|c|c|c|c|c|}
\hline Variables & Tests & M.U & Average & Std. & Main & Skewness \\
\hline \multirow{4}{*}{$\begin{array}{c}\text { Basics } \\
\text { measurements }\end{array}$} & Tall & C.Ms & 164.045 & 10.926 & 165.5 & -0.646 \\
\hline & Age & Years & 15.590 & 0.834 & 16.000 & -0.058 \\
\hline & Bodyweight & k.gs & 68.227 & 8.686 & 66.500 & 0.280 \\
\hline & Training age & Years & 1.955 & 0.638 & 2.000 & 0.042 \\
\hline \multirow{6}{*}{ ME tests } & Clean repetition & Numbers & 10.045 & 1.147 & 10.000 & -0.289 \\
\hline & Jerk repetition & Numbers & 7.045 & 1.151 & 7.000 & -0.291 \\
\hline & Snatch repetition & Numbers & 6.409 & 1.029 & 6.000 & 0.666 \\
\hline & Front Squat repetition & Numbers & 11.818 & 1.302 & 12.000 & 0.498 \\
\hline & Back Squat repetition & Numbers & 13.045 & 1.331 & 13.000 & 0.284 \\
\hline & Clean pull-up repetition & Numbers & 14.182 & 2.014 & 14.000 & 0.234 \\
\hline \multirow[b]{2}{*}{ CA test } & $\begin{array}{c}\text { Competition Simulation } \\
\text { snatch }\end{array}$ & $\begin{array}{l}\text { N.successful } \\
\text { attempts }\end{array}$ & 1.545 & 0.582 & 1.500 & 0.553 \\
\hline & $\begin{array}{c}\text { Competition Simulation } \\
\text { clean and jerk }\end{array}$ & $\begin{array}{l}\text { N.successful } \\
\text { attempts }\end{array}$ & 1.455 & 0.497 & 1.000 & 0.196 \\
\hline
\end{tabular}

The results of skewness were from -0.646 (tall results as the lowest value) to 0.666 (snatch repetition test as the highest value), and all results between \pm 3 proved that there are no differences between the whole samples in basic measurement and ME and CA. and the sample is matched before the experimental.

Table 2 shows the average and standard deviation for the two groups including control and experimental in basic measurement and ME and CA. In addition, t. test in order to test the parity between the two groups statistically.

Table 2

Average, std. deviation, $t$ test between the pretest of the experimental group and control group in basics measurements, ME test and EA test

\begin{tabular}{|c|c|c|c|c|c|c|c|}
\hline \multirow{2}{*}{ Variables } & \multirow{2}{*}{ Tests } & \multirow{2}{*}{ M.U } & \multicolumn{2}{|c|}{ Experimental group $(n=11)$} & \multicolumn{2}{|c|}{ Control group $(\mathrm{n}=11)$} & \multirow[t]{2}{*}{ T. Test } \\
\hline & & & Average & Std. & Average & Skewness & \\
\hline \multirow{7}{*}{$\begin{array}{c}\text { Basics } \\
\text { measurements }\end{array}$} & Tall & C.Ms & 162.909 & 8.774 & 165.182 & 11.1422 & 0.308 \\
\hline & Age & Years & 15.636 & 0.643 & 15.545 & 0.987 & 0.405 \\
\hline & Bodyweight & k.gs & 66.364 & 8.260 & 70.090 & 8.701 & 0.169 \\
\hline & Training age & Years & 2.0901 & 0.668 & 1.818 & 0.575 & 0.169 \\
\hline & Clean repetition & Numbers & 9.818 & 1.192 & 10.273 & 1.052 & 0.188 \\
\hline & Jerk repetition & Numbers & 7.182 & 0.936 & 6.909 & 1.311 & 0.299 \\
\hline & Snatch repetition & Numbers & 6.455 & 0.987 & 6.364 & 1.067 & 0.423 \\
\hline \multirow[t]{3}{*}{ ME tests } & $\begin{array}{l}\text { Front Squat } \\
\text { repetition }\end{array}$ & Numbers & 11.545 & 1.012 & 12.091 & 1.505 & 0.175 \\
\hline & $\begin{array}{l}\text { Back Squat } \\
\text { repetition }\end{array}$ & Numbers & 12.909 & 1.239 & 13.182 & 1.402 & 0.325 \\
\hline & $\begin{array}{l}\text { Clean pull-up } \\
\text { repetition }\end{array}$ & Numbers & 13.908 & 1.379 & 14.454 & 2.463 & 0.274 \\
\hline CA test & $\begin{array}{c}\text { Competition } \\
\text { Simulation snatch }\end{array}$ & N.successful & 1.454 & 0.498 & 1.636 & 0.643 & 0.244 \\
\hline
\end{tabular}




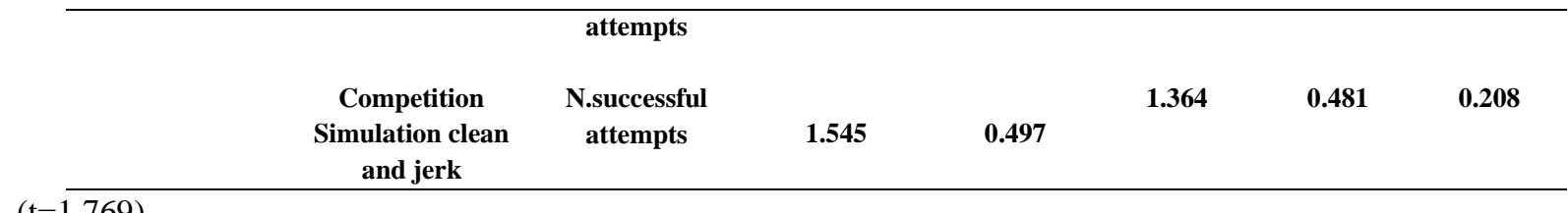

$(\mathrm{t}=\overline{1.769)}$

This table illustrates the differences between the two groups (experimental - control) statistically through T. test. The results between 0.169 for the both measurements of bodyweight and training age to 0.423 for snatch repetition test, the entire t. test results $<1.769$ this proves that there are no differences between the two groups. In addition, the two groups are well matches to conduct the research.

Table 3, table 4 display the T. Test between the pre-test and post-test for the (experimental- control) groups in ME tests and CA tests in order to explore the differences between them.

Table 3

Average, std. deviation, $t$ test between the pre-test and post-test for the experimental group in basics measurements, ME test and EA test $(n=11)$

\begin{tabular}{|c|c|c|c|c|c|c|c|}
\hline \multirow{2}{*}{ Variables } & \multirow{2}{*}{ Tests } & \multirow{2}{*}{ M.U } & \multicolumn{2}{|c|}{ Pre-test } & \multicolumn{2}{|c|}{ Post-test } & \multirow{2}{*}{ T. Test } \\
\hline & & & Average & Std. & Average & Std. & \\
\hline \multirow{6}{*}{ ME tests } & Clean repetition & Numbers & 9.818 & 1.192 & 15.182 & 0.936 & 2.313 \\
\hline & Jerk repetition & Numbers & 7.182 & 0.936 & 11.454 & 0.987 & 1.778 \\
\hline & Snatch repetition & Numbers & 6.455 & 0.987 & 12.273 & 2.004 & 3.716 \\
\hline & $\begin{array}{c}\text { Front Squat } \\
\text { repetition }\end{array}$ & Numbers & 11.545 & 1.012 & 18.636 & 1.772 & 2.864 \\
\hline & $\begin{array}{l}\text { Back Squat } \\
\text { repetition }\end{array}$ & Numbers & 12.909 & 1.239 & 20.000 & 2.045 & 4.617 \\
\hline & $\begin{array}{l}\text { Clean pull-up } \\
\text { repetition }\end{array}$ & Numbers & 13.908 & 1.379 & 20.091 & 1.164 & 4.050 \\
\hline \multirow[b]{2}{*}{ CA test } & $\begin{array}{c}\text { Competition } \\
\text { Simulation snatch }\end{array}$ & $\begin{array}{l}\text { N.successful } \\
\text { attempts }\end{array}$ & 1.454 & 0.498 & 2.818 & 0.385 & 5.912 \\
\hline & $\begin{array}{c}\text { Competition } \\
\text { Simulation clean } \\
\text { and jerk }\end{array}$ & $\begin{array}{l}\text { N.successful } \\
\text { attempts }\end{array}$ & 1.545 & 0.497 & 2.727 & 0.445 & 8.909 \\
\hline
\end{tabular}

$(\mathrm{t}=1.7 \overline{69)}$

The table depicts that there is a significant difference between the pre-test and post-test for the experimental group in all the tests used and it is obvious that $\mathrm{T}$. test values are between 1.778 (jerk repetition test) and 8.909 (competition simulation clean and jerk) and they are all over 1.769 (T. test table value)

This means that the CrossFit program has a good impact on the two sides, which purposed to develop, and to discover the improvement rates accurately should comparing the two post-tests results in control and experimental groups after applying the two programs original and approach.

Table 4

Average, std. deviation, $t$ test between the pre-test and post-test for the control group in basics measurements, ME test and EA test $(n=11)$

\begin{tabular}{lccccccc}
\hline \multirow{2}{*}{ Variables } & \multirow{2}{*}{ Tests } & \multirow{2}{*}{ M.U } & \multicolumn{2}{c}{ Pre-test } & \multicolumn{2}{c}{ Post-test } & \multirow{2}{*}{ T. Test } \\
\cline { 4 - 7 } & & & Average & Std. & Average & Std. & \\
\hline \multirow{2}{*}{ ME tests } & Clean repetition & Numbers & 10.273 & 1.052 & 12.818 & 1.266 & 4.37 \\
& \multirow{2}{*}{ Jerk repetition } & Numbers & \multirow{2}{*}{6.909} & 1.311 & 9.091 & 0.793 & \multirow{2}{*}{0.001} \\
\hline
\end{tabular}




\begin{tabular}{|c|c|c|c|c|c|c|c|}
\hline & Snatch repetition & Numbers & 6.364 & 1.067 & 8.545 & 1.076 & 9.694 \\
\hline & $\begin{array}{l}\text { Front Squat } \\
\text { repetition }\end{array}$ & Numbers & 12.091 & 1.505 & 15.182 & 1.527 & 9.518 \\
\hline & $\begin{array}{l}\text { Back Squat } \\
\text { repetition }\end{array}$ & Numbers & 13.182 & 1.402 & 15.728 & 0.962 & 6.367 \\
\hline & $\begin{array}{l}\text { Clean pull-up } \\
\text { repetition }\end{array}$ & Numbers & 14.454 & 2.463 & 17.455 & 1.305 & 0.002 \\
\hline \multirow[b]{2}{*}{ CA test } & $\begin{array}{c}\text { Competition } \\
\text { Simulation snatch }\end{array}$ & $\begin{array}{l}\text { N.successful } \\
\text { attempts }\end{array}$ & 1.636 & 0.643 & 1.727 & 0.445 & 0.358 \\
\hline & $\begin{array}{c}\text { Competition } \\
\text { Simulation clean } \\
\text { and jerk }\end{array}$ & $\begin{array}{l}\text { N.successful } \\
\text { attempts }\end{array}$ & 1.364 & 0.481 & 1.545 & 0.498 & 0.208 \\
\hline
\end{tabular}

The table shows a significant difference between the pre-test and post-test for the control group in some ME tests (clean repetition - snatch repetition - front squat repletion - back squat repetition) because the T. test values were higher than 1.7689T.test (table value).

This results mean that there is a devolvement occurred to the weightlifters and appeared in some physical movements but this improvement didn't had effect enough on technical movements, which proves that the usually program is effective, but it needs to be modified or maybe replaced with new training methods.

The other tests of ME (jerk repetition - clean pull up repetition) and for the CA tests (competition simulation Snatch - competition simulation Snatch) there is no differences between the pre-test and post-test because T. test values are between 0.001 and 0.358 and it's all less than $1.769 \mathrm{~T}$. test (table value)

As it is observe in the table, CA tests results, which represented in the competition simulation have not improved and this figures out that the research aim is important because it is one of the primary aims to improve through applying the CrossFit program.

Table 5 shows that $\mathrm{T}$. test between the post-tests of the two groups (experimental -control) and the improvement percent

Table 5

Average, std. deviation, $t$ test between the post-tests for the experimental group and control group in basics measurements, ME test and EA test $(n=11)$

\begin{tabular}{|c|c|c|c|c|c|c|c|c|}
\hline \multirow{2}{*}{ Variables } & \multirow{2}{*}{ Tests } & \multirow{2}{*}{ M.U } & \multicolumn{2}{|c|}{ Experimental post-test } & \multicolumn{2}{|c|}{ Control Post-test } & \multirow{2}{*}{ T. Test } & \multirow{2}{*}{$\begin{array}{l}\text { Improvem } \\
\text { ent percent }\end{array}$} \\
\hline & & & Average & Std. & Average & Std & & \\
\hline \multirow{6}{*}{ ME tests } & Clean repetition & Numbers & 15.182 & 0.936 & 12.818 & 1.266 & 6.163 & $18.439 \%$ \\
\hline & Jerk repetition & Numbers & 11.454 & 0.987 & 9.091 & 0.793 & 4.484 & $26.000 \%$ \\
\hline & Snatch repetition & Numbers & 12.273 & 2.004 & 8.545 & 1.076 & 2.265 & $43.617 \%$ \\
\hline & $\begin{array}{l}\text { Front Squat } \\
\text { repetition }\end{array}$ & Numbers & 18.636 & 1.772 & 15.182 & 1.527 & 7.359 & $22.754 \%$ \\
\hline & $\begin{array}{l}\text { Back Squat } \\
\text { repetition }\end{array}$ & Numbers & 20.000 & 2.045 & 15.728 & 0.962 & 3.796 & $27.168 \%$ \\
\hline & $\begin{array}{l}\text { Clean pull-up } \\
\text { repetition }\end{array}$ & Numbers & 20.091 & 1.164 & 17.455 & 1.305 & 5.875 & $15.104 \%$ \\
\hline CA test & $\begin{array}{c}\text { Competition } \\
\text { Simulation snatch }\end{array}$ & $\begin{array}{l}\text { N.successf } \\
\text { ul attempts }\end{array}$ & 2.818 & 0.385 & 1.727 & 0.445 & 4.981 & $63.158 \%$ \\
\hline
\end{tabular}




\begin{tabular}{cccccccc}
\hline $\begin{array}{c}\text { Competition } \\
\text { Simulation clean } \\
\text { and jerk }\end{array}$ & $\begin{array}{c}\text { N.successf } \\
\text { ul attempts }\end{array}$ & 2.727 & 0.445 & 1.545 & 0.498 & 8.909 & $76.471 \%$ \\
\hline
\end{tabular}

$(\mathrm{t}=1.769)$

The table illustrates that there is a significant difference between the tests results of the two groups because the whole tests results values are over than 1.769 (T. test table value).

\section{Discussion}

Table 3 results show that there are a differences between the two results pre-tests and post- tests for the experimental group in ME and CA; where the development of muscular endurance for example; clean repetition average were 9.818 and become 15.182 after applying cross-fit program with a difference of 5.364. Jerk repetition average were 7.182 and become 11.454 with a difference of 4.272 , snatch repetition were 6.455 and become 12.273 with a difference 5.818, front squat repetition from 11.545 and become 18.636 with a difference of 7.091. Back squat repetition from 12.909 , become 20.00 with a difference of 7.091 , clean pull-up repetition from 13.908 , and become 20.091 with a difference of 6.183 .

This improvement in muscular endurance after applying CrossFit program referee to the mechanism of CrossFit drills as it should contain moving large loads over long distance collectively and quickly including three main components (quickness, loads, distance) and that's should improve muscular endurance, and that's agree with results of (Barfield, J. P., \& Anderson, A., 2014)

On the other side, the improvement in consecutive attempts numbers observed for example; average numbers of successful attempts case in snatch were 1.454 and become 2.818 with a difference of 1.364 , and for clean and jerk average were 1.545 and become 2.727 with a difference of 1.182 , that's referee to chosen exercises relevant to the competition performance.

Table 4 illustrates in control group that there are significant improvements in some tests styles for muscular endurance for example; clean repetition was 10.273 and become 12.818 with 2.545 differences but the improvements in the last part of the lift jerk repetition wasn't significant statistically where the average was 6.909 and become 9.091 with 2.182 . That is lead to necessity of training by compounded exercises to collect more than one part/movement in one motion/exercise.

In addition to that, there is improvements appeared in snatch repetition, which was 6.364 , and become 8.545 with 2.181, front repetition test was 12.091 and become 15.182 with 3.091 differences, and back squat repetition was 13.182 and become 15.728 with 2.546 differences. In addition, there is no significant differences in clean pull-up (deadlift) repetition, which was 14.454 and become 17.455 with 3.001 differences.

For consecutive attempts, there is no any significant differences for the control group in both lifts snatch and clean and jerk, the results were; snatch competition simulation 1.636 and become 1.727 with 0.091 differences and clean and jerk competition simulation was 1.364 and become 1.545 with 0.181 differences.

If we compared differences between the two groups in muscular endurance tests results, we will found that all tests in experimental group had significant improvements with high differences more than control group results, which had significant improvements only in four of six tests with low differences, and without any significant improvements in consecutive attempts.

Table 5 results show The ME six tests developing, for example, the average of clean repetition in experimental group is $15.182 \pm 0.936$, but it is $12.818 \pm 1.266$ in control group with improvement percent $18.439 \%$. This percent refer to the nature of CrossFit drills that execute always compounded and the clean skill is the same motor, which executes compounded from pull and front squat. 
The next ME test is jerk repetition, its average $11.454 \pm 0.987$ for the experimental group and $9.091 \pm 0.793$ for the control group with improvement percent $18.439 \%$ to the experimental group results, the jerk is an important motor skill, which should execute in a vertical line to avoid losing power and failure. Weightlifters also try to do that in CrossFit drills always pushing straight in vertical lines for the same reason.

Snatch repetition test (ME) average in experimental group $12.273 \pm 2.004$ and $8.545 \pm 1.076$ for the control group with improvement percent $26.00 \%$, by observation, the improvement in snatch is more than clean and jerk.

Snatch is completely depends on good technique (how should the weightlifters be in touch in every stage with the barbell), also in CrossFit drills the weightlifters always try to be in touch and reduce the space between them and the tool to reduce force and resistance. Consequently, the CrossFit enhances the technique, which will improve the record level. (Baumann, W., Gross, V., Quade, K., Galbierz, P., \& Schwirtz, A.,1988)

For the following three (ME tests), Front squat repetition test average 18.636 \pm 1.772 for experimental group, and $15.527 \pm 1.527$ in control group with $22.754 \%$ percent improvement, back squat repetition tests which its average $20.00 \pm 2.045$ for experimental group and $15.728 \pm 0.962$ for control group with $27.168 \%$ improvement percent. Clean pull-up (deadlift) repetition test, which its average in experimental group is $20.091 \pm 1.64$ and in control group is $17.455 \pm 1.305$ with $15.104 \%$ improvement percent. That all developed with high degrees.

This development could refer to CrossFit drills technique that depends on big muscles like legs and back muscles that led to high improvements percent in the three tests and its reflects improvement in muscular endurance to the same muscle groups in this tests. (Paine, J., Uptgraft, J., \& Wylie, R. 2010; EBADA, K. A. R.,2011; Aján, T., \& Baroga, L.,1988; Awad, A,2018)

As is displayed CA tests, competition simulations of snatch successful attempts average is $2.818 \pm 0.385$ in experimental group and $1.727 \pm 0.445$ for control group with $63.158 \%$ improvement percent. Second, competition simulations of clean\&jerk successful attempts average is $2.727 \pm 0.445$ in experimental group and $1.545 \pm 0.498$ for control group with $76.471 \%$ improvement percent.

This figures out that weightlifters ability to execute and repeat the same attempts in high weight without a complete recovery and success in lift has improved in a very good way. This numbers of successful attempts improvements could refer to the improvement of ME generally. (Lee, C.,1990; Anton, M. M., Spirduso, W. W., \& Tanaka, H. I. R. O. F. U. M. I.,2004)

This does not happen to the control group because the muscular endurance improved enough to affect consecutive attempts successful number, and this proves that this improvement is a reason of muscular improvement.

\section{Conclusion}

There are significant differences between experimental group results and control group results at muscular endurance and numbers of successful attempts at consecutive attempts cases, this means the CrossFit program is a successful method to train weightlifters and to improve their performance and results, and therefore, it recommended using this method in weightlifting training.

\section{References}

Anton, M. M., Spirduso, W. W., \& Tanaka, H. I. R. O. F. U. M. I. (2004). Age-related declines in anaerobic muscular performance: weightlifting and powerlifting. Medicine and science in sports and exercise, 36(1), 143147. 
Anderson, T., \& Kearney, J. T. (1982). Effects of three resistance training programs on muscular strength and absolute and relative endurance. Research Quarterly for Exercise and Sport, 53(1), 1-7.

Awad, A . (2018). Outcome strength of weightlifters, bilateral limb deficit, relative strength and its relationship to Women Arab Championships results (senior) 2017. Turkish Journal of Kinesiology, 4 (1), 26-32. DOI: 10.31459/turkjkin.408903.

Barfield, J. P., \& Anderson, A. (2014). Effect of CrossFit ${ }^{\mathrm{TM}}$ on health-related physical fitness: A pilot study. Journal of Sport and Human Performance, 2(1).

Baumann, W., Gross, V., Quade, K., Galbierz, P., \& Schwirtz, A. (1988). The snatch technique of world class weightlifters at the 1985 world championships. International Journal of Sport Biomechanics, 4(1), 68-89.

Baumann, W., Gross, V., Quade, K., Galbierz, P., \& Schwirtz, A. (1988). The snatch technique of world class weightlifters at the 1985 world championships. International Journal of Sport Biomechanics, 4(1), 68-89.

Bompa, T. O., \& Buzzichelli, C. (2018). Periodization-: theory and methodology of training. Human Kinetics.

Ebada, K. H. (2013). The impact of ballistic training on explosive power development and some biomechanics parameters for lifting the snatch youth weightlifters. In International sport science student's conference (ISSSC 2013) from (Vol. 28).

Eather, N., Morgan, P. J., \& Lubans, D. R. (2016). Improving health-related fitness in adolescents: the CrossFit Teens $^{\mathrm{TM}}$ randomised controlled trial. Journal of sports sciences, 34(3), 209-223.

Glassman, G., 2010, The Cross Fit Training Guide, The Cross Fit Journal, http://library.crossfit.com/free/pdf/CFJ_Sem inars_TrainingGuide_REV122011.pdf., 1112.

Garhammer, J., \& Takano, B. (1992). Training for weightlifting. Strength and power in sport, 2.

Lee, C. (1990). Psyching up for a muscular endurance task: Effects of image content on performance and mood state. Journal of Sport and Exercise Psychology, 12(1), 66-73.

Hamill, B. (1994). Relative safety of weightlifting and weight training. J Strength Cond Res, 8(1), 53-57.

Hagberg, M. A. T. S. (1981). Muscular endurance and surface electromyogram in isometric and dynamic exercise. Journal of Applied Physiology, 51(1), 1-7.

IWF Technical and Competition Rules \& Regulations 2019; https://www.iwf.net/downloads/?did=598

Izquierdo, M., Ibáñez, J., Häkkinen, K., Kraemer, W. J., Ruesta, M., \& Gorostiaga, E. M. (2004). Maximal strength and power, muscle mass, endurance and serum hormones in weightlifters and road cyclists. Journal of sports sciences, 22(5), 465-478.

EBADA, K. A. R. (2011). The effect of a training program on the development of the maximal strength for weightlifting beginner's performance. methods, $14,42$.

Smith, M. M., Sommer, A. J., Starkoff, B. E., \& Devor, S. T. (2013). Crossfit-based high-intensity power training improves maximal aerobic fitness and body composition. J Strength Cond Res, 27(11), 3159-3172.

Sibley, B. A. (2012). Using sport education to implement a CrossFit unit. Journal of Physical Education, Recreation \& Dance, 83(8), 42-48.

Aján, T., \& Baroga, L. (1988). Weightlifting: fitness for all sports. International Weightlifting Federation.

Paine, J., Uptgraft, J., \& Wylie, R. (2010). CrossFit study. Command and General Staff College, 1-34. 


\section{First attachment (CROSSFIT Program)}

The program lasted for 8 weeks, 3 unitslworkouts per week" Saturday, Monday, Wednesday", every unit duration 120 minutes, and it started from Saturday 1\9\2018 to Wednesday 24\10\2018.

\begin{tabular}{|c|c|c|c|c|c|c|c|}
\hline & Day & Exercises Circuit & $\begin{array}{c}\text { Intensity } \\
\text { (1RM) }\end{array}$ & Repetitions & $\begin{array}{c}\text { Sets } \\
\text { Duration }\end{array}$ & $\begin{array}{c}\text { Recovery } \\
\text { duration } \\
\text { between } \\
\text { sets }\end{array}$ & $\begin{array}{l}\text { Exercise } \\
\text { duration }\end{array}$ \\
\hline \multirow{10}{*}{$\frac{\bar{Z}}{3}$} & \multirow{4}{*}{ Saturday } & $\begin{array}{l}\text { - Power clean \& } \\
\text { Power jerk }\end{array}$ & $50-60 \%$ & 6 & $20 \mathrm{M}$ & $60 \mathrm{~S}$ & $30 \mathrm{M}$ \\
\hline & & $\begin{array}{l}\text { - Front Shoulder } \\
\text { press \& Back } \\
\text { squat \& snatch }\end{array}$ & $55-65 \%$ & 7 & $20 \mathrm{M}$ & $60 \mathrm{~S}$ & $30 \mathrm{M}$ \\
\hline & & $\begin{array}{l}\text { - Jump rope \& Set } \\
\text { up }\end{array}$ & $60-70 \%$ & 16 & $20 \mathrm{M}$ & $60 \mathrm{~S}$ & $30 \mathrm{M}$ \\
\hline & & \multicolumn{6}{|c|}{ Warm up: $15 \mathrm{~m} \&$ cool down: $10 \mathrm{~m}$} \\
\hline & \multirow{4}{*}{ Monday } & $\begin{array}{l}\text { - Back shoulder } \\
\text { press \& Clean } \\
\text { classic \& Back } \\
\text { squat }\end{array}$ & $60-70 \%$ & 7 & $20 \mathrm{M}$ & $60 \mathrm{~S}$ & $30 \mathrm{M}$ \\
\hline & & $\begin{array}{l}\text { - Power snatch \& } \\
\text { Back squat \& } \\
\text { Back extension }\end{array}$ & $65-75 \%$ & 8 & $20 \mathrm{M}$ & $60 \mathrm{~S}$ & $30 \mathrm{M}$ \\
\hline & & $\begin{array}{l}\text { - Jump rope \& } \\
\text { chin up }\end{array}$ & $60-70 \%$ & 15 & $20 \mathrm{M}$ & $60 \mathrm{~S}$ & $30 \mathrm{M}$ \\
\hline & & \multicolumn{6}{|c|}{ Warm up: $15 \mathrm{~m} \&$ cool down: $10 \mathrm{~m}$} \\
\hline & \multirow{2}{*}{ Wednesday } & $\begin{array}{l}\text { - Power snatch \& } \\
\text { Front squat \& } \\
\text { Deadlift }\end{array}$ & $65-75 \%$ & 6 & $20 \mathrm{M}$ & $60 \mathrm{~S}$ & $30 \mathrm{M}$ \\
\hline & & $\begin{array}{l}\text { - Power clean \& } \\
\text { Back squat \& } \\
\text { Good morning }\end{array}$ & $70-80 \%$ & 7 & $20 \mathrm{M}$ & $60 \mathrm{~S}$ & $30 \mathrm{M}$ \\
\hline
\end{tabular}




\begin{tabular}{|c|c|c|c|c|c|c|c|}
\hline & & $\begin{array}{l}\text { - Sit-up \& Hang } \\
\text { up }\end{array}$ & $60-70 \%$ & 17 & $20 \mathrm{M}$ & $60 \mathrm{~S}$ & $30 \mathrm{M}$ \\
\hline & & \multicolumn{6}{|c|}{ Warm up: $15 \mathrm{~m} \&$ cool down: $10 \mathrm{~m}$} \\
\hline \multirow{12}{*}{$\frac{2}{2}$} & \multirow{4}{*}{ Saturday } & $\begin{array}{l}\text { - Snatch classic \& } \\
\text { box }(50 \text { c) jump }\end{array}$ & $70-80 \%$ & 5 & $20 \mathrm{M}$ & $60 \mathrm{~S}$ & $30 \mathrm{M}$ \\
\hline & & $\begin{array}{l}\text { - Back squat \& } \\
\text { back shoulder } \\
\text { press \& front bar } \\
\text { lunges }\end{array}$ & $75-85 \%$ & 7 & $20 \mathrm{M}$ & $60 \mathrm{~S}$ & $30 \mathrm{M}$ \\
\hline & & $\begin{array}{l}\text { - Deadlift \& } \\
\text { biceps curl \& } \\
\text { front raise }\end{array}$ & $80-85 \%$ & 6 & $20 \mathrm{M}$ & $60 \mathrm{~S}$ & $30 \mathrm{M}$ \\
\hline & & \multicolumn{6}{|c|}{ Warm up: $15 \mathrm{~m} \&$ cool down: $10 \mathrm{~m}$} \\
\hline & \multirow{4}{*}{ Monday } & $\begin{array}{l}\text { - Power Clean \& } \\
\text { power jerk }\end{array}$ & $70-80 \%$ & 7 & $20 \mathrm{M}$ & $60 \mathrm{~S}$ & $30 \mathrm{M}$ \\
\hline & & $\begin{array}{l}\text { - Front squat \& } \\
\text { box }(50 \mathrm{c}) \text { jump }\end{array}$ & $80-85 \%$ & 6 & $20 \mathrm{M}$ & $60 \mathrm{~S}$ & $30 \mathrm{M}$ \\
\hline & & $\begin{array}{l}\text { - Deadlift \& leg } \\
\text { raise \& sit-up }\end{array}$ & $80-90 \%$ & 9 & $20 \mathrm{M}$ & $60 \mathrm{~S}$ & $30 \mathrm{M}$ \\
\hline & & \multicolumn{6}{|c|}{ Warm up: $15 \mathrm{~m} \&$ cool down: $10 \mathrm{~m}$} \\
\hline & \multirow{4}{*}{ Wednesday } & $\begin{array}{l}\text { - Snatch classic \& } \\
\text { hoping in place }\end{array}$ & $80-90 \%$ & 5 & $20 \mathrm{M}$ & $60 \mathrm{~S}$ & $30 \mathrm{M}$ \\
\hline & & $\begin{array}{l}\text { - Back squat \& } \\
\text { back shoulder } \\
\text { press \& bench } \\
\text { dip }\end{array}$ & $70-80 \%$ & 6 & $20 \mathrm{M}$ & $60 \mathrm{~S}$ & $30 \mathrm{M}$ \\
\hline & & $\begin{array}{l}\text { - Rope jump \& } \\
\text { back lunges }\end{array}$ & $75-85 \%$ & 7 & $20 \mathrm{M}$ & $60 \mathrm{~S}$ & $30 \mathrm{M}$ \\
\hline & & \multicolumn{6}{|c|}{ Warm up: $15 \mathrm{~m} \&$ cool down: $10 \mathrm{~m}$} \\
\hline \multirow{8}{*}{$\begin{array}{l}m \\
\text { ñ } \\
3\end{array}$} & \multirow{4}{*}{ Saturday } & $\begin{array}{l}\text { - Clean and jerk \& } \\
\text { hoping in place }\end{array}$ & $85-90 \%$ & 5 & $20 \mathrm{M}$ & $60 \mathrm{~S}$ & $30 \mathrm{M}$ \\
\hline & & $\begin{array}{l}\text { - Front squat \& } \\
\text { front shoulder } \\
\text { press \& back } \\
\text { extension }\end{array}$ & $80-85 \%$ & 6 & $20 \mathrm{M}$ & $60 \mathrm{~S}$ & $30 \mathrm{M}$ \\
\hline & & $\begin{array}{l}\text { - Chin up \& } \\
\text { biceps curl \& } \\
\text { good morning }\end{array}$ & $70-80 \%$ & 9 & $20 \mathrm{M}$ & $60 \mathrm{~S}$ & $30 \mathrm{M}$ \\
\hline & & \multicolumn{6}{|c|}{ Warm up: $15 \mathrm{~m} \&$ cool down: $10 \mathrm{~m}$} \\
\hline & \multirow{4}{*}{ Monday } & $\begin{array}{l}\text { - Snatch \& hoping } \\
\text { in place }\end{array}$ & $80-90 \%$ & 5 & $20 \mathrm{M}$ & $60 \mathrm{~S}$ & $30 \mathrm{M}$ \\
\hline & & $\begin{array}{l}\text { - Deadlift \& front } \\
\text { lunges \& push } \\
\text { up }\end{array}$ & $70-80 \%$ & 6 & $20 \mathrm{M}$ & $60 \mathrm{~S}$ & $30 \mathrm{M}$ \\
\hline & & $\begin{array}{l}\text { - Sit-up \& back } \\
\text { extension }\end{array}$ & $80-90 \%$ & 14 & $20 \mathrm{M}$ & $60 \mathrm{~S}$ & $30 \mathrm{M}$ \\
\hline & & \multicolumn{6}{|c|}{ Warm up: $15 \mathrm{~m} \&$ cool down: $10 \mathrm{~m}$} \\
\hline
\end{tabular}




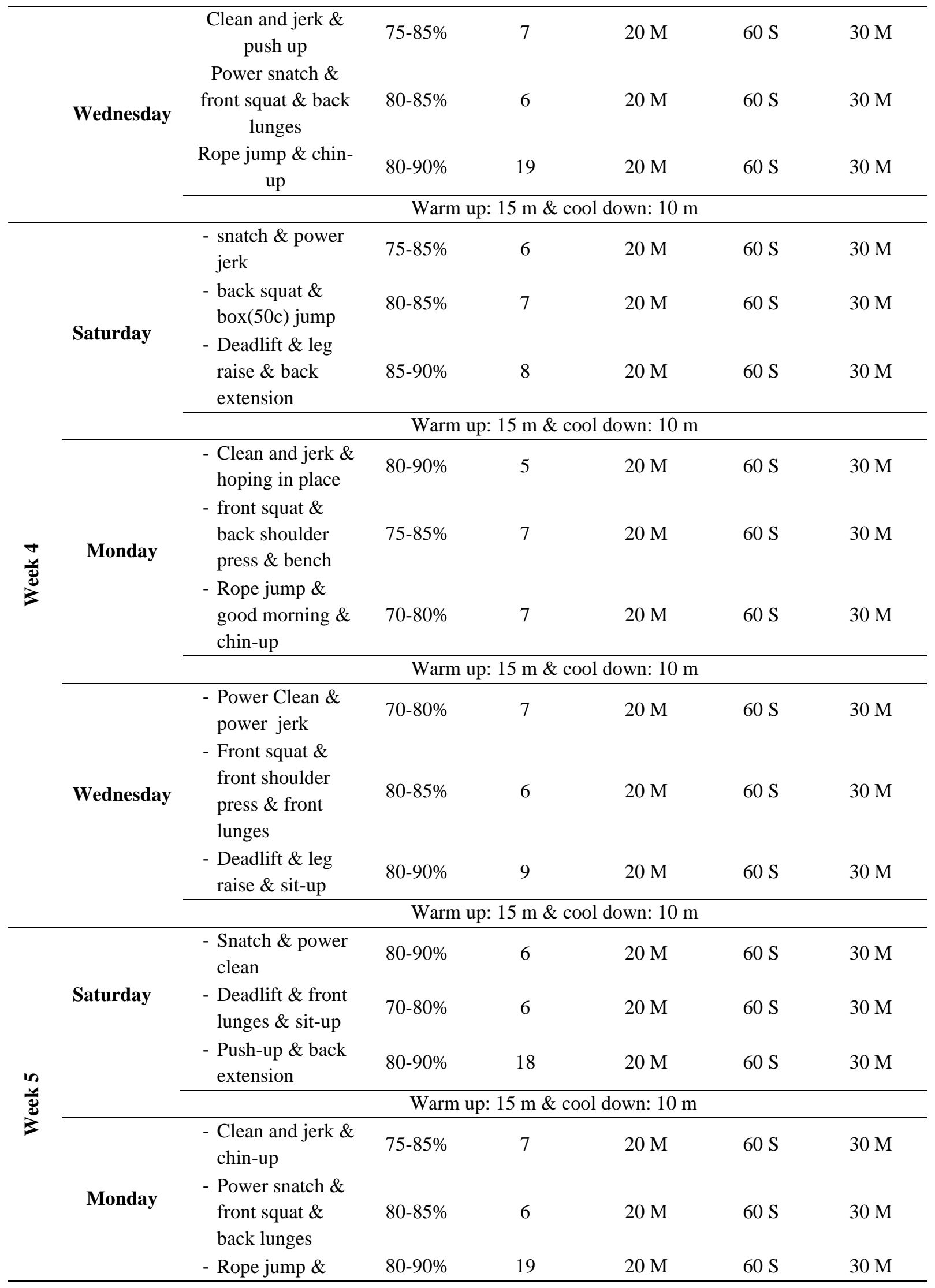




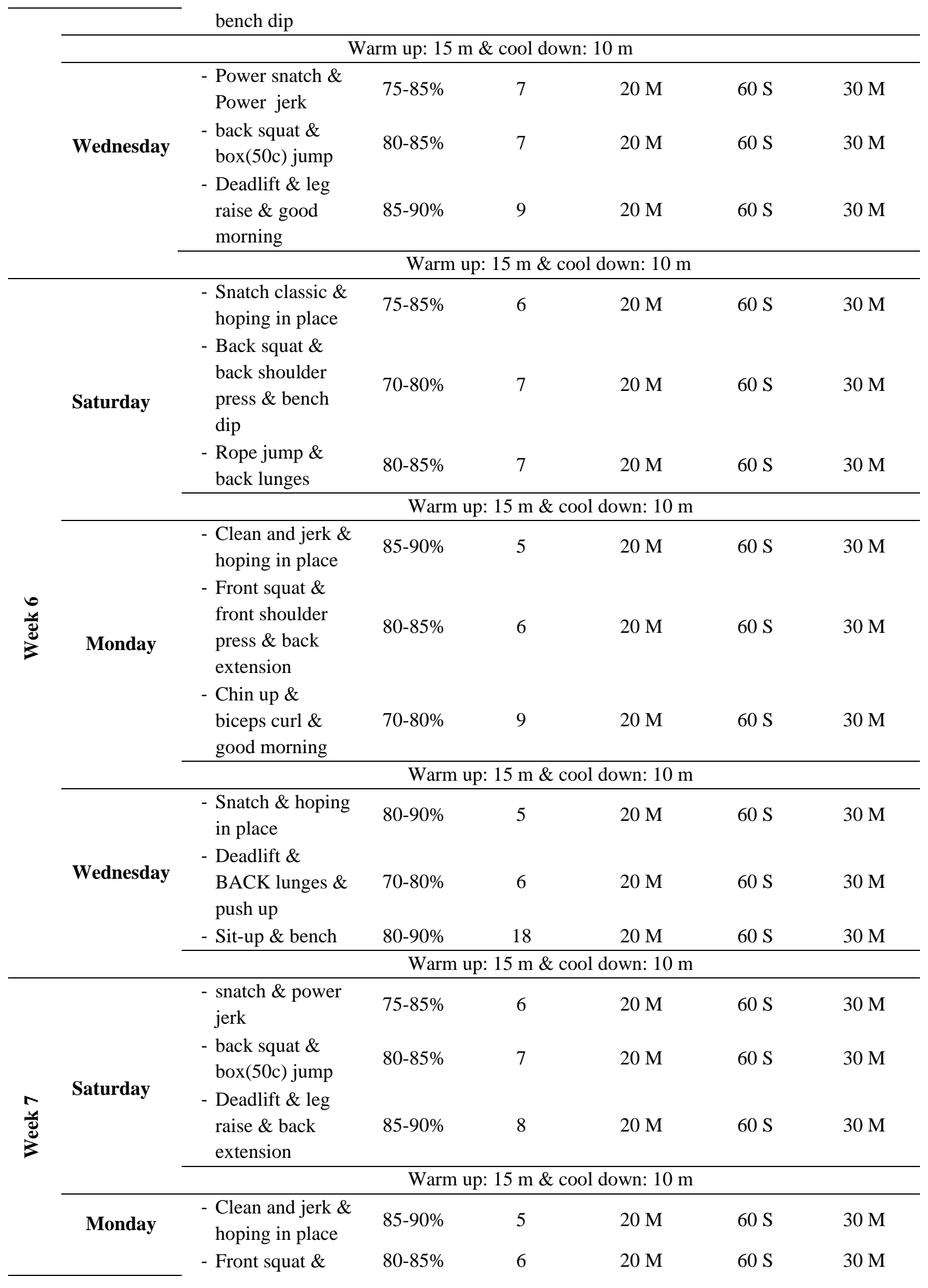




\begin{tabular}{|c|c|c|c|c|c|c|c|}
\hline & & $\begin{array}{l}\text { front shoulder } \\
\text { press \& back } \\
\text { extension } \\
\text { - Chin up \& } \\
\text { biceps curl \& } \\
\text { good morning }\end{array}$ & $70-80 \%$ & 9 & $20 \mathrm{M}$ & $60 \mathrm{~S}$ & $30 \mathrm{M}$ \\
\hline & & \multicolumn{6}{|c|}{ Warm up: $15 \mathrm{~m} \&$ cool down: $10 \mathrm{~m}$} \\
\hline & \multirow{4}{*}{ Wednesday } & $\begin{array}{l}\text { - Power Clean \& } \\
\text { power jerk }\end{array}$ & $70-80 \%$ & 7 & $20 \mathrm{M}$ & $60 \mathrm{~S}$ & $30 \mathrm{M}$ \\
\hline & & $\begin{array}{l}\text { - Front squat \& } \\
\text { front shoulder } \\
\text { press \& front } \\
\text { lunges }\end{array}$ & $80-85 \%$ & 6 & $20 \mathrm{M}$ & $60 \mathrm{~S}$ & $30 \mathrm{M}$ \\
\hline & & $\begin{array}{l}\text { - Deadlift \& leg } \\
\text { raise \& sit-up }\end{array}$ & $80-90 \%$ & 9 & $20 \mathrm{M}$ & $60 \mathrm{~S}$ & $30 \mathrm{M}$ \\
\hline & & \multicolumn{6}{|c|}{ Warm up: $15 \mathrm{~m} \&$ cool down: $10 \mathrm{~m}$} \\
\hline \multirow{11}{*}{$\begin{array}{l}\infty \\
\frac{1}{0} \\
\sum^{0}\end{array}$} & & $\begin{array}{l}\text { - Snatch \& power } \\
\text { clean }\end{array}$ & $80-90 \%$ & 6 & $20 \mathrm{M}$ & $60 \mathrm{~S}$ & $30 \mathrm{M}$ \\
\hline & Saturday & $\begin{array}{l}\text { - Deadlift \& front } \\
\text { lunges \& sit-up }\end{array}$ & $70-80 \%$ & 6 & $20 \mathrm{M}$ & $60 \mathrm{~S}$ & $30 \mathrm{M}$ \\
\hline & & $\begin{array}{l}\text { - Push-up \& back } \\
\text { extension }\end{array}$ & $80-90 \%$ & 18 & $20 \mathrm{M}$ & $60 \mathrm{~S}$ & $30 \mathrm{M}$ \\
\hline & & \multicolumn{6}{|c|}{ Warm up: $15 \mathrm{~m} \&$ cool down: $10 \mathrm{~m}$} \\
\hline & & $\begin{array}{l}\text { - Clean and jerk \& } \\
\text { hoping in place }\end{array}$ & $80-90 \%$ & 5 & $20 \mathrm{M}$ & $60 \mathrm{~S}$ & $30 \mathrm{M}$ \\
\hline & Monday & $\begin{array}{l}\text { - front squat \& } \\
\text { back shoulder } \\
\text { press \& bench }\end{array}$ & $75-85 \%$ & 7 & $20 \mathrm{M}$ & $60 \mathrm{~S}$ & $30 \mathrm{M}$ \\
\hline & & $\begin{array}{l}\text { - Rope jump \& } \\
\text { good morning \& } \\
\text { chin-up }\end{array}$ & $70-80 \%$ & 16 & $20 \mathrm{M}$ & $60 \mathrm{~S}$ & $30 \mathrm{M}$ \\
\hline & & \multicolumn{6}{|c|}{ Warm up: $15 \mathrm{~m} \&$ cool down: $10 \mathrm{~m}$} \\
\hline & \multirow{3}{*}{ Wednesday } & $\begin{array}{l}\text { - Snatch classic \& } \\
\text { hoping in place }\end{array}$ & $80-90 \%$ & 5 & $20 \mathrm{M}$ & $60 \mathrm{~S}$ & $30 \mathrm{M}$ \\
\hline & & $\begin{array}{l}\text { - Back squat \& } \\
\text { back shoulder } \\
\text { press \& bench } \\
\text { dip }\end{array}$ & $70-80 \%$ & 6 & $20 \mathrm{M}$ & $60 \mathrm{~S}$ & $30 \mathrm{M}$ \\
\hline & & $\begin{array}{l}\text { - Rope jump \& } \\
\text { back lunges }\end{array}$ & $75-85 \%$ & 17 & $20 \mathrm{M}$ & $60 \mathrm{~S}$ & $30 \mathrm{M}$ \\
\hline
\end{tabular}




\section{Second attachment (tests)}

Test name

Aim of test

Tools

Measurement unite

Scientific Factors

Performance

Test confirmation

Points
: Clean Repetition

: Measure muscular endurance

. Bar - weights - platform

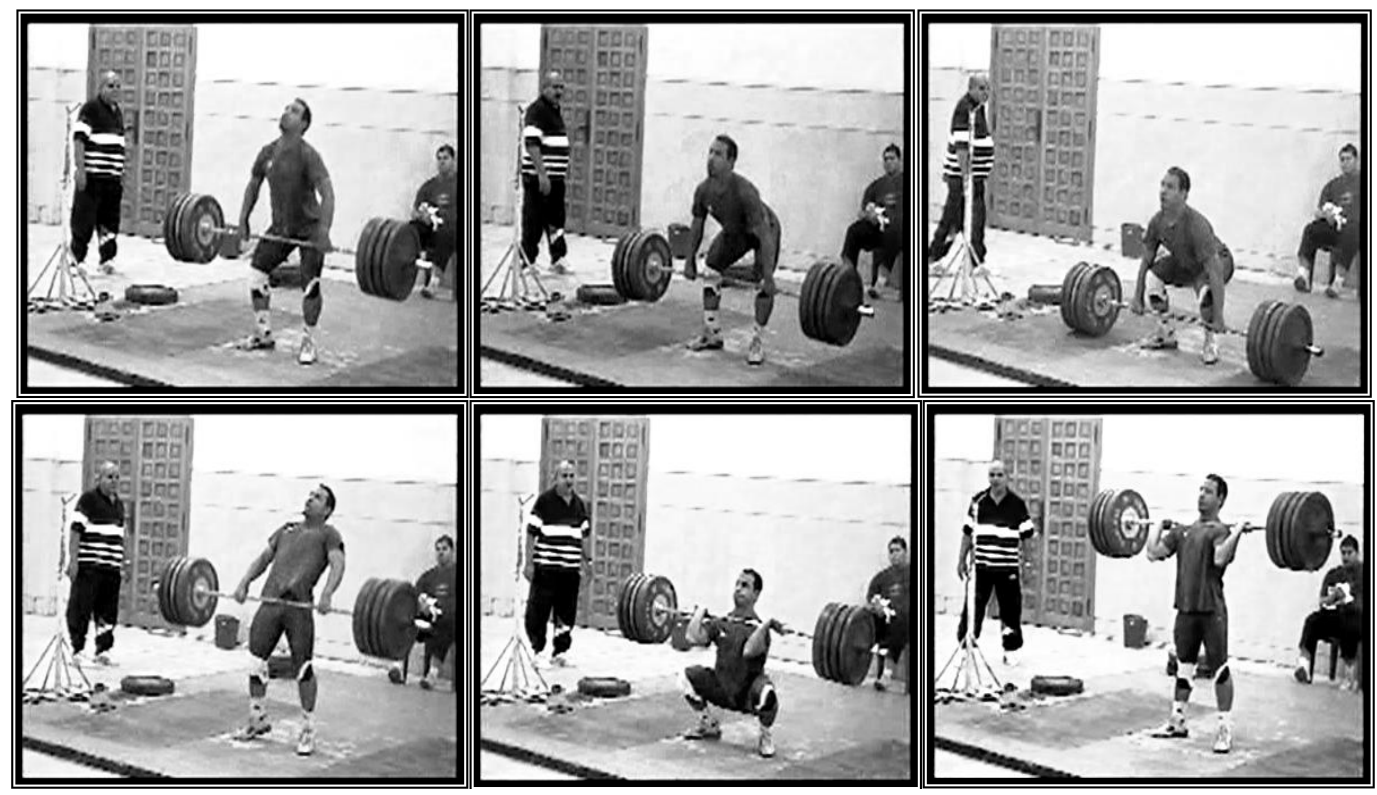


Test name

Aim of test

Tools

Measurement unite

Scientific Factors

Performance

Test confirmation

Points
: Jerk Repetition

: Measure muscular endurance

: Bar - weights - platform

: Repetition

: Validity $=0.893 \&$ stability $=0.797 \&$ objectively $=0.967$

Weightlifter take jerk start position (barbell on his chest), and then he push the barbell in one movement above head to the top of his arms (full extension), finally he pulls his feet side by side and stand without any flexion in his body joints.

: Warm up - straight back - looking forward

: Every complete movement $=1$ point 


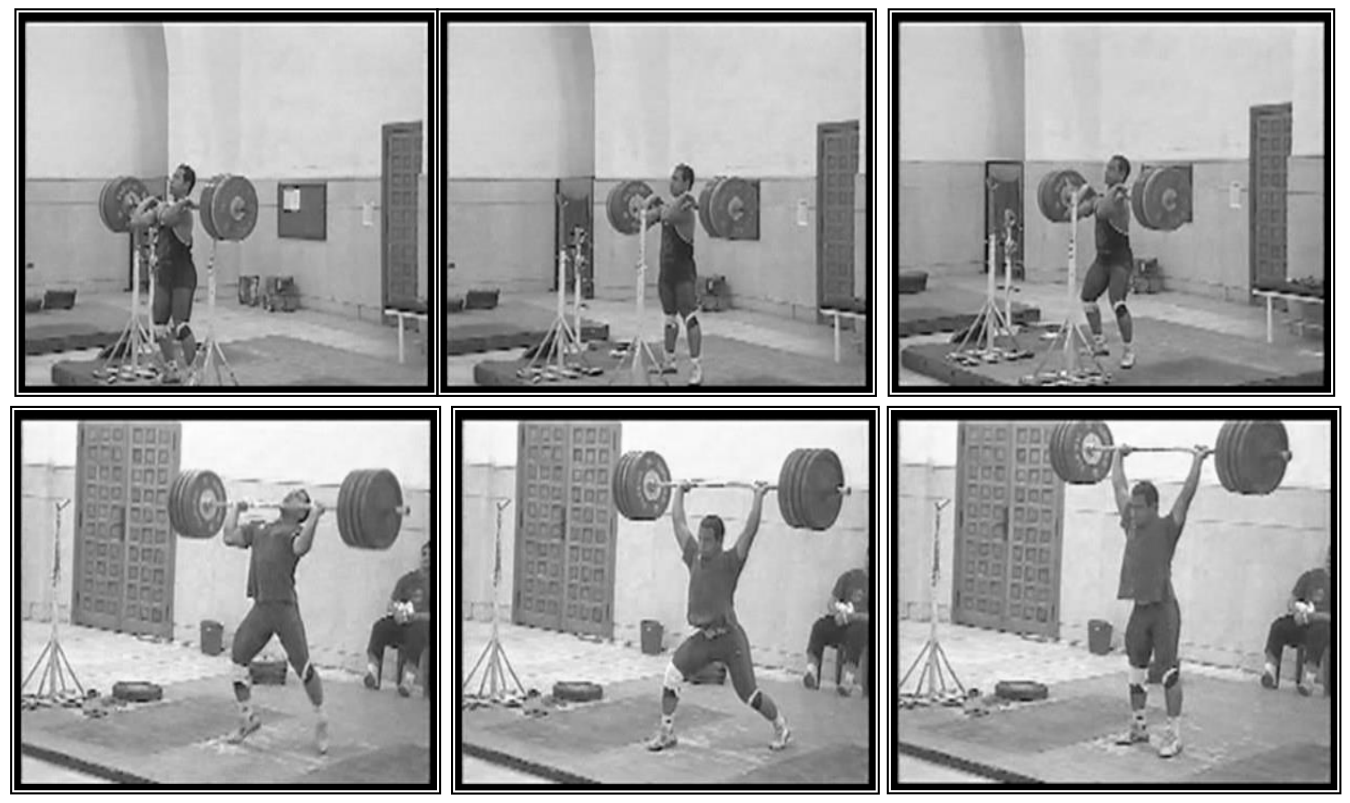

Test name $\quad$ Snatch Repetition

Aim of test : Measure muscular endurance

Tools $\quad$ : Bar - weights - platform

Measurement unite $\quad$ Repetition

Scientific Factors $\quad: \quad$ Validity $=0.908 \&$ stability $=0.824 \&$ objectively $=0.982$

Weightlifter take clean start position, and then he lift the bar in one

Performance : movement above head to the top of his arms (full extension), finally stand up with the barbell.

Test confirmation $\quad$ : Warm up- feet almost hip width- straight back - looking forward

Points $\quad$ : Every complete movement $=1$ point 

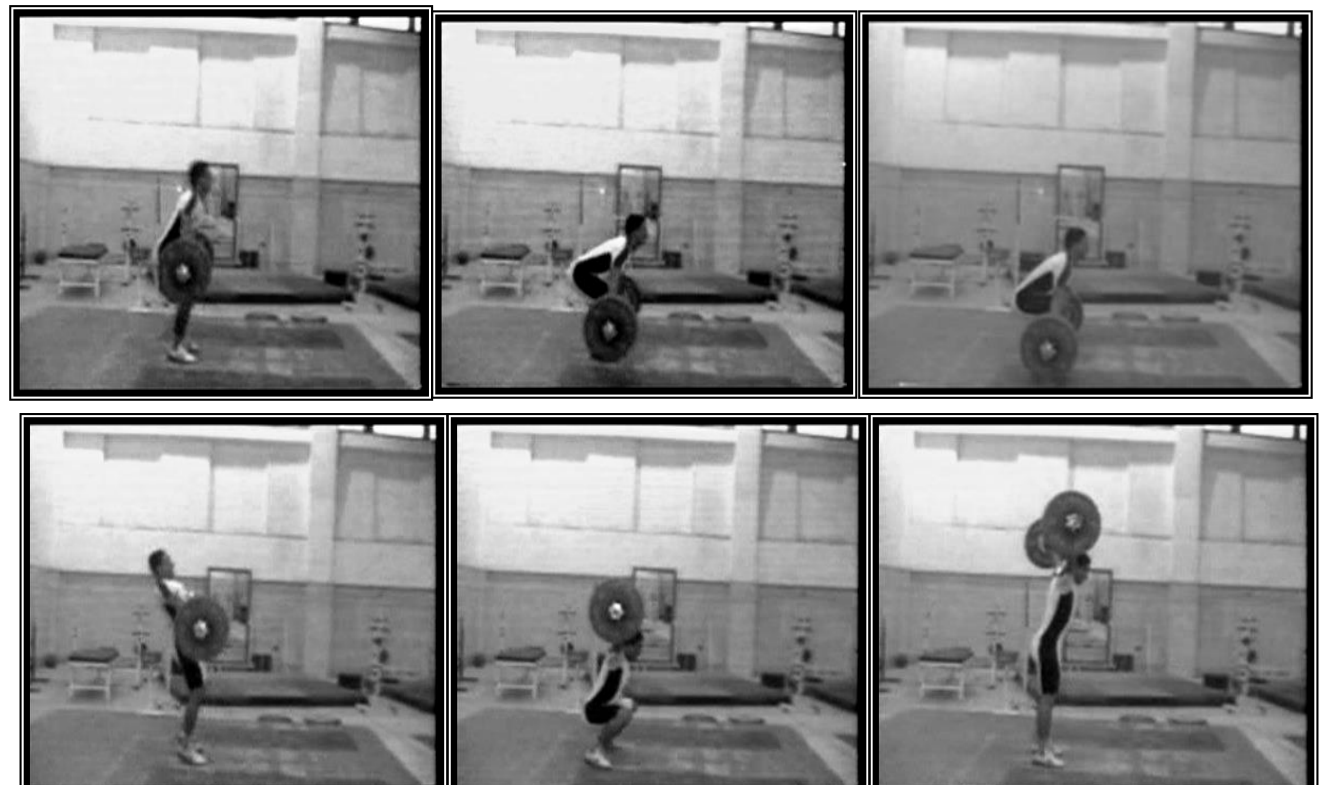

Test name $\quad$ : Front squat Repetition

Aim of test

Tools

Measurement unite

Scientific Factors

Performance

Test confirmation

Points
: Measure muscular endurance

. Bar - weights - platform

: Repetition

: Validity $=0.987 \&$ stability $=0.975 \&$ objectively $=0.997$

Weightlifter hold the barbell on his shoulders (top chest), and repeat bending and extending the knee.

: Warm up- feet almost hip width- straight back - looking forward

: Every complete movement $=1$ point 


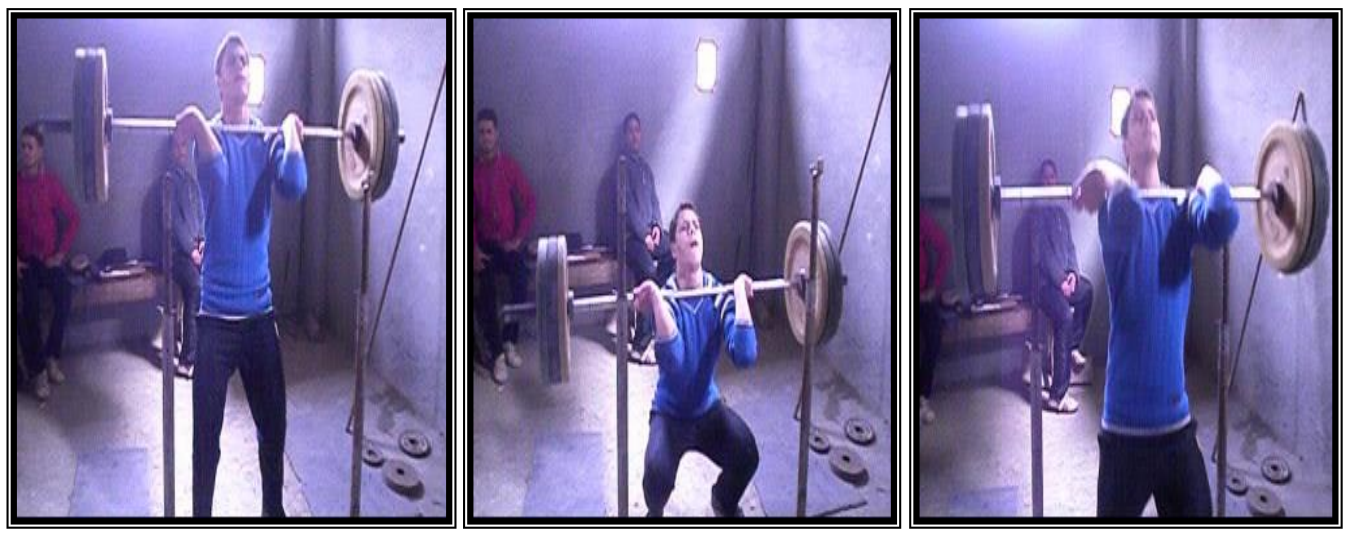

Test name ： back squat Repetition

Aim of test $\quad:$ Measure muscular endurance

Tools

: Bar - weights - platform

Measurement unite

: Repetition

Scientific Factors $\quad: \quad$ Validity $=0.989 \&$ stability $=0.979 \&$ objectively $=0.981$

Performance : $\begin{aligned} & \text { Weightlifter hold the barbell } \\ & \text { bending and extending the knee. }\end{aligned}$

Test confirmation $\quad:$ Warm up- feet almost hip width- straight back - looking forward 


\section{Points}

: Every complete movement $=1$ point
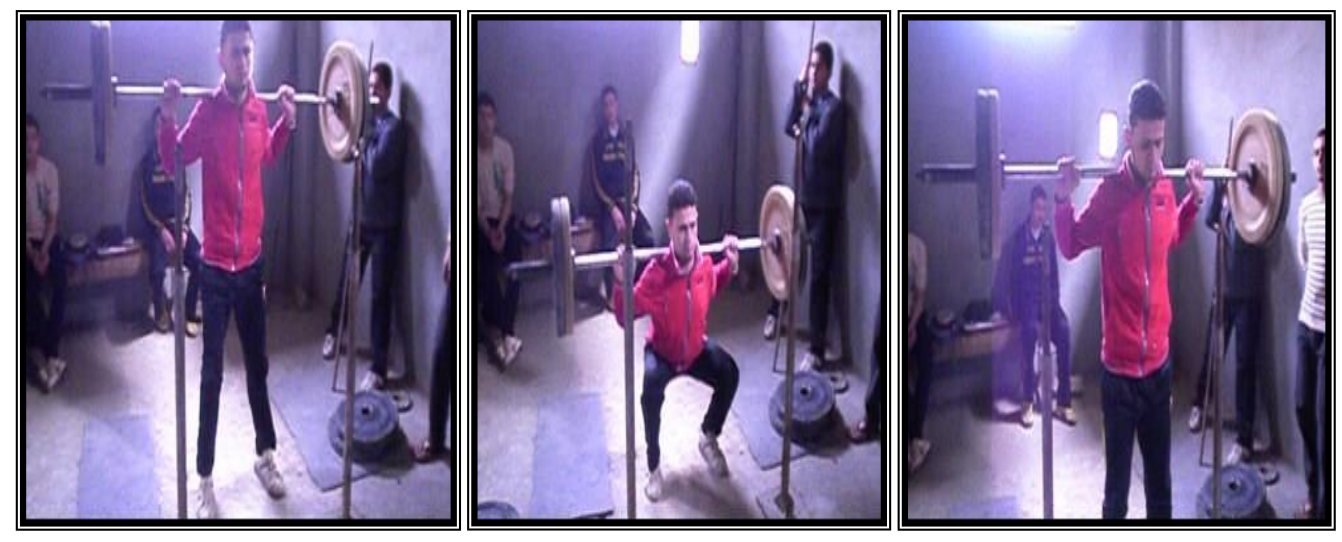

Test name

Aim of test

Tools

Measurement unite

Scientific Factors

Performance

Test confirmation
: Clean Pull-up (deadlift) Repetition

: Measure muscular endurance

. Bar - weights - platform

: Validity $=0.983 \&$ stability $=0.966$ \& objectively $=0.971$

Weightlifter take clean start position to lift the bar, and then he lift the bar

: to heist point of thighs as possible (full extended back and knees), finally release the barbell back to platform and repeat

: Warm up- feet almost hip width- straight back - looking forward 
Points : Every complete movement $=1$ point

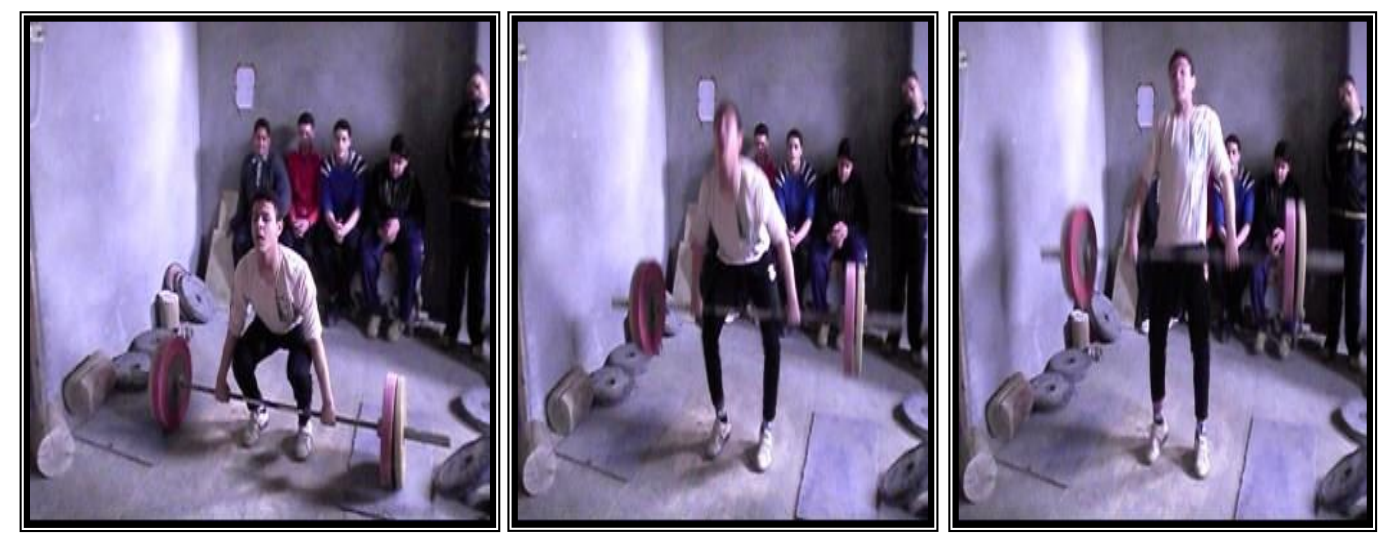

